\title{
Immunohistochemical expression levels of anterior pituitary LH, FSH and testicular testosterone of Allium sativum extract and thymoquinone in male treated rats
}

\author{
N.F. Hassan \\ College of Pharmacy, University of Al-Qadisiyah, Al-Qadisiyah, Iraq, Email: neeran.hassan@qu.edu.iq
}

(Received October 7, 2017; Accepted November 29, 2017)

\begin{abstract}
The present study was conducted to determine the immunohistochemical expression levels of Luteinizing Hormone and Follicle Stimulating Hormone in the anterior pituitary gland and testicular testosterone of male rats treated with Allium sativum extract and Thymoquinone. Forty mature Waster male rats Rattus norvegicus, aged 60 days and weighed 140-150 g, were randomly divided into control and three treatment groups (10 rats each). Control group males were orally supplemented with $500 \mu \mathrm{L}$ of normal saline daily. The treated groups of males were orally supplemented with TQ suspension, $50 \mathrm{mg} / \mathrm{kg}, \mathrm{B}$.Wt (TQ group), Allium sativum aqueous extract, $50 \mathrm{mg} / \mathrm{kg}$ bw (A group) and their combination (TQA group). At the end of experiment, all male rats were sacrificed and pituitaries and testes were dissected and fixed in neutral formalin buffer $10 \%$ for immunohistochemical examination of pituitary LH and FSH and testicular testosterone. The results demonstrated high immunohistochemical density in treated male's pituitary tissues for both LH and FSH compared with the control group. In comparison with control, testicular tissues of treated group males showed stronger immune reaction for $\mathrm{T}$ especially around Lydig's and Sertoli cells. It can be concluded that TQ and Allium sativum have potent improving effects on reproductive hormones production and could be increase the male fertility.
\end{abstract}

Keywords: LH, FSH, Pituitary, Testes, Thymoquinone, Allium sativum Available online at http://www.vetmedmosul.org/ijvs

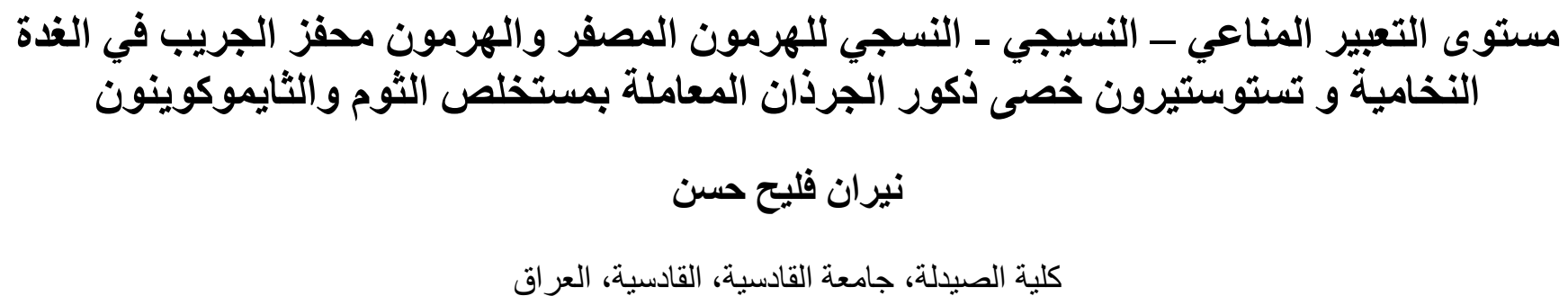

أجريت الدر اسة الحالية لتحديد مستوى التعبير المناعي النسجي الكيميائي للهرمون المصفر و الهرمون محفز الجريب في الغدة النخامية

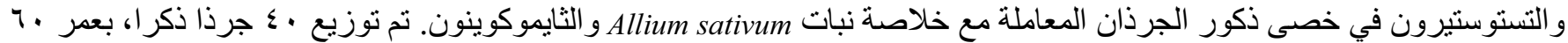

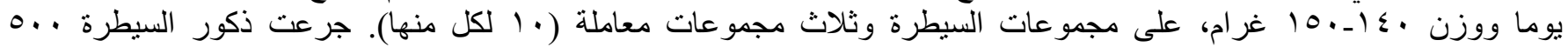

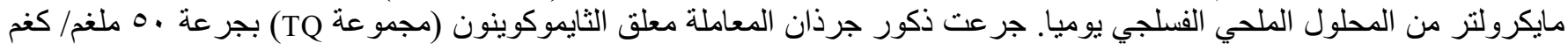

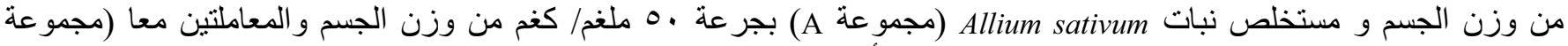

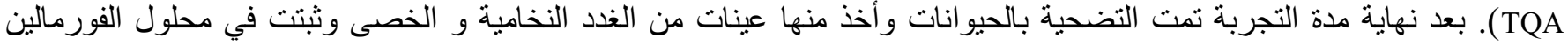

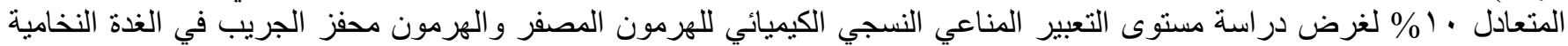

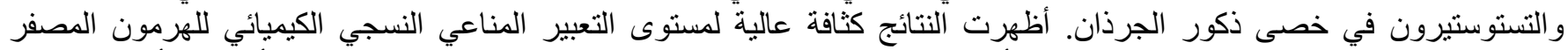
و الهرمون محفز الجريب في الغدد النخامية المأخوذة من ذكور المعاملات الثناث بالمقارنة مع السيطرة. كما أظهرت أنسجة خصى 


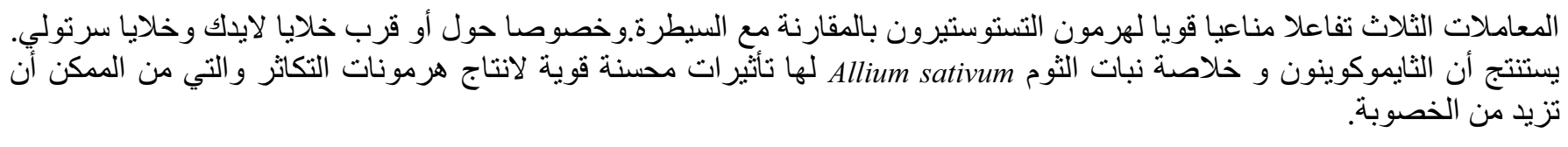

\section{Introduction}

Medicinal plants and their components have been used as medicines for health since ancient times and many countries in the world rely on traditional medicine for primary health care. Medical plants opened a new window to research in disease prevention and treatment. Several studies have been conducted to clarify the therapeutic effects of black seed ingredients in the treatment and prevention of infertility through their role in modifying antioxidants, anti-inflammatory, liver and other genetic activities (1).

Since TQ is the vital active compound of oils extracted from the black seed, the last 15 years illustrated hundreds of research reports on the knowledge of its therapeutic vitality as anti-inflammatory, analgesic, anti-diabetic, antihistaminic and anti-cancer agent (2). TQ is a natural plant chemical compound isolated from black seed oil (Nigella sativa), a traditional herb from Southwest Asia, the main ingredient of black bean, which accounts for about $50 \%$ of volatile oils that have significant therapeutic properties such as: analgesics, anti-inflammatory, protection of devices against oxidative stress damage, as well as antibiotic properties (3).

Garlic (Allium sativum) and its preparations have been investigated extensively for health benefits, resulting in numerous research reports over the last decade alone. It is considered one of the best disease-preventive foods, based on its potent and varied effects. Over the centuries, garlic has acquired a special position in the tradition of many cultures as a formidable prophylactic and therapeutic medicinal agent (4). Its uses as a remedy for heart disease, tumours, and headaches are documented in the Egyptian Cordex Ebers dating from 1550 BC. Garlic has been used as a traditional treatment in many countries notably the Near East, China, and India $(5,6)$. This plant has attracted particular attention of modern medicine because it helps to maintain good health by prevention and treatment of cardiovascular diseases $(7,8)$. Garlic has been used in oriental medicine, to improve male sexual dysfunction since ancient times, and it has beneficial effect in the recovery of testicular functions (9), while other authors reported the spermicidal effect of garlic $(10,11)$.

The endocrine control of sperm formation and the production of steroid in the testis is due to the action of pituitary hormones on the cells in the testicle of Lydic cells and sertoli cells (12). The frontal lobe of the pituitary gland produces many hormones including LH and FSH (13). The function of the FSH in males is necessary to stimulate reproduction, as it works on Sertoli cells, while LH plays an important role in stimulating the Leydig cells to build androgen hormones, mainly acting on the testosterone hormone $(14,15)$. The lipid hormone is the primary hormone responsible for the development and maintenance of secondary sexual characteristics $(16,17)$.

The present study was designed to examine the role of TQ and Allium Sativum extract on the reproductive hormones production and their effect on male fertility, by determining the immunohistochemical expression levels of pituitary LH and FSH and testicular testosterone.

\section{Materials and methods}

\section{Preparation of $A$. sativum extract}

Allium sativum aqueous extract has been prepared according to Harborne (18).

\section{Preparation of TQ}

TQ has been prepared by suspending $10 \mathrm{~g} \mathrm{ml}$ of TQ crystals (Sigma Aldrich, UK) in $100 \mathrm{~mL}$ of distilled water. According to male rat's body weight, the suspension was used as $500 \mu \mathrm{L}(50 \mathrm{mg}) / \mathrm{kg}$ of body weight $(19,20)$.

\section{Experimental animals}

Adult male Wistar rats (aged 60 days and weighted 140$150 \mathrm{~g})$ have been housed in a controlled ambient temperature $\left(22-25^{\circ} \mathrm{C}\right)$ and $12: 12$ dark and light. The animals were fed on standard food and drinking water ad libitum.

\section{Experimental design}

Forty male rats have been assigned randomly to four equal groups (10 for each) and treated as follow: Control (C group): daily drenched with $500 \mu \mathrm{L}$ of distilled water for 4 weeks. TQ treatment (TQ group): daily drenched with TQ suspension $(50 \mathrm{mg} / \mathrm{kg} \mathrm{B} . \mathrm{Wt})$ for 4 weeks. A. sativum treatment (A group): daily drenched with $A$. sativum aqueous extract $(50 \mathrm{mg} / \mathrm{kg} \quad \mathrm{B} . \mathrm{Wt})$ for 4 weeks. Combination treatment (TQA group): daily drenched with TQ suspension $(50 \mathrm{mg} / \mathrm{kg} \mathrm{B}$.Wt) plus $A$. sativum aqueous extract (50 mg/ kg B.Wt) for 4 weeks.

After 24 hours of the last treatment, male rats have been sacrificed, pituitary glands and testes were dissected and fixed in neutral buffer formalin $(10 \%)$ for ICH examination. 


\section{Methods}

Histological sections have been prepared and stained with Haematoxylin and Eosin stains (21) and ICH evaluation were performed in accordance to Abcam company instructions. In the ICH analysis, positive readings were indicated by a brown cytoplasmic stain, whereas, negative readings were indicated by the absence of immune reactions in the negative control.

\section{IHC Kits}

The following kits have been used in the present study: Anti- FSH monoclonal mouse (5900) to FSH Reacts with mouse, rat, human at $-20{ }^{\circ} \mathrm{C} 0.2 \mathrm{mg} / \mathrm{mL}$ (Abcam Co.), Anti-LH monoclonal mouse (7500) to LH Reacts with: mouse, rat, human at $-20^{\circ} \mathrm{C} 0.1 \mathrm{mg} / \mathrm{mL}$ (Abcam Co.), Anti - Testosterone rabbit polyclonal to Testosterone $0.2 \mathrm{mg} /$ $\mathrm{mL}$ at $-20{ }^{\circ} \mathrm{C}$ (Abcam Co.) and ICH detection kit (Abcam Co.).

\section{Results}

IHC expression of FSH in the glandular tissues of the pituitary gland

The IHC results of pituitary FSH in the present study showed strong positive immune response (high density of interaction) in gonadotrophs as well as interstitial fluid of the glandular partition of the gland. Stronger positive interactions were shown in the TQ, A and TQA group male rats in comparison with control group males (figure 1).

\section{IHC expression of $\mathrm{LH}$ in the glandular tissues of the pituitary gland}

In figure (2), the three treated group male rats (TQ, A and TQA groups) revealed high immune interaction with LH in the gonadotrophs of the pituitary tissues, where the IHC density of the positive immune reaction localized mainly inside and around the gonadotrophs, whereas control group males showed less strength and intensity of the immune reaction.

\section{IHC expression of $T$ in the testes}

The results demonstrated in figure (3) clarified higher IHC expression levels of testosterone in the testicular tissues of treated group males compared with control group males. The positive immune reaction concentrated inside and around Leydic and Sertoli cells.

\section{Discussion}

Medicinal herbal substances are important for therapeutic uses, particularly in fertility cases, especially in males, because these substances have natural and harmless ingredients (1). Therefore, in our study we used TQ and $A$. sativum extract as single or in combination and has been found to have a strong effect on reproductive hormones production in mature male rats.

The results of adenohypophysis IHC examination of FSH in all treated groups of male rats showed higher density than control group males which was in agreement with (22), where it has been noted that treatment with black seed oil leads to increased concentrations of sex hormones in cadmium exposed male rats. The increased density of FSH and LH expression is clearly indicated by the action of $\mathrm{TQ}$, as it can be inferred by increasing the number of cells producing or increasing their production, which may be through the role of TQ on growth hormone production. It has been described by Hull and Harvey (23) that growth hormone is important in controlling the function of growth and sexual maturity.

The present increase in the number of gonadotrophs and observed IHC density in all groups due to the present treatment may be through hypothalamic control on pituitary gonagotropic hormones secretion. This is in agreement with the study that conducted on mature rats treated with black seed oil as the results showed that there is a significant increase in levels of FSH and LH which can be attributed to the direct effect of the active ingredient TQ on the hypothalamus $(24,25)$.

Regarding A. sativum extract, several studies, in vivo and in vitro, have reported the impairment of spermatogenesis after treatment with garlic and its metabolites. Dixit and Joshi (26) reported that chronic administration of $50 \mathrm{mg}$ of garlic powder to adult rat over 70 days induced a spermatogenetic arrest at the primary spermatocyte stage. Moreover, aqueous garlic extract (11) and the metabolite diathyltrisulphide (10) have spermicidal effects on adult rats. In contrast, Al-Bekairi et al. (27) reported an increase in epididymal spermatozoa after feeding mice with $100 \mathrm{mg} \mathrm{kg}$ aqueous garlic extract over 3 months. Another study did not show any change in epididymis sperm density after 1 month of treatment of adult rat with $10 \%, 15 \%$ and $30 \%$ crude garlic (28). This discrepancy in the studies could be linked to differences in the garlic preparation, the period length and the dose of treatment. In the present study, it can be agreed with that reported by Al-Bekairi et al. (27) and Hammami et al. (28).

Testosterone is essential for spermatogenesis completion because it stimulates the conversion of round spermatids into elongated spermatids between stage VII and stage VIII of the spermatogenetic cycle (29). A limited number of studies investigated the effect of garlic on testosterone. One study reported that the consumption of crude garlic at $5 \%, 10 \%, 15 \%$ and $30 \%$, by adult rats, reduces testosterone secretion and alters spermatogenesis (28). The reduction in circulating and intratesticular testosterone levels was associated with elevated LH levels 
suggesting a diminished responsiveness of Leydig cells to LH and/or a direct inhibition of testicular steroidogenesis and as such a testicular alteration in the gonadotrophintestosterone axis. In contrast, Oi et al. (30) indicated that increased testicular testosterone concentrations after treatment with $8 \mathrm{~g}$ of garlic powder are associated with an increase in LH plasma levels. This discrepancy could be attributed to the different types of garlic preparations that do not contain the same active compounds. Biosynthesis of serum cholesterol, the vital testosterone precursor, was not changed in the study by Hammami et al. (28), while Dixit and Joshi (26) demonstrated an inhibition of cholesterol biosynthesis in rat serum and liver. In this context, the different steps of testosterone biosynthesis were evaluated. Conversion of cholesterol to biologically active testosterone is a multi-step enzymatic process, including Star that controls the transport of cholesterol from the outer to the inner mitochondrial membrane, Cyp11a1, Hsd17b3 and Hsd3b5 (31). Garlic was shown to alter testosterone production, as Star, Cyp11a1, Hsd17b3 and Hsd3b5, mRNA levels were decreased in a dose-dependent manner. Given that testosterone protects germ cells, especially spermatocytes and spermatids, against apoptosis (31-33), its decrease induced by garlic consumption might be an explanation for the death of spermatocyte and spermatid cells via an apoptotic process, while interestingly, garlic extract is known to reduce serum cholesterol levels and inhibit cholesterol biosynthesis (34). Alteration in testosterone production was not related to cholesterol metabolism but to steroidogenic enzyme modification (35).

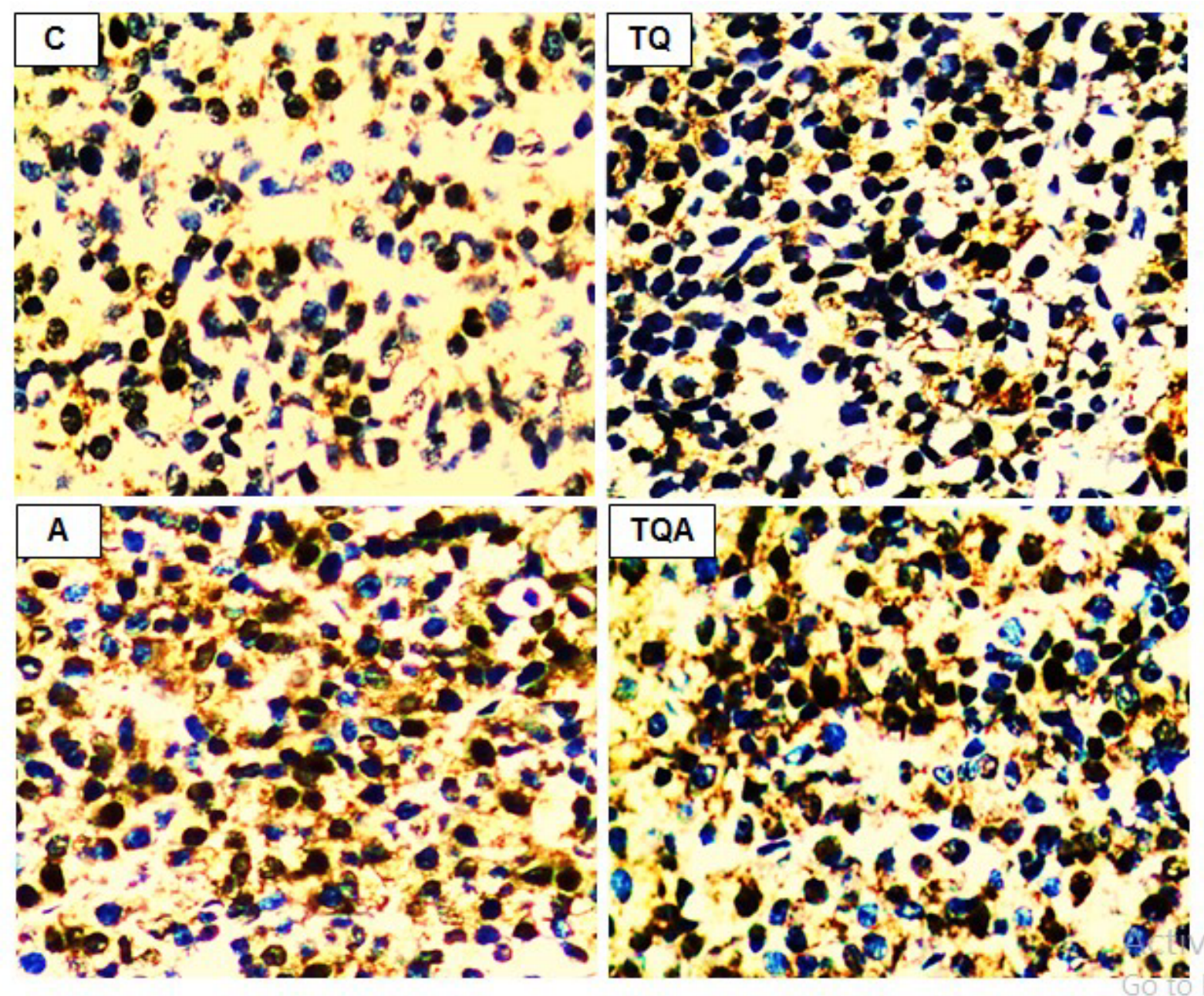

Figure (1): Sections obtained from adenohypophysis of control (C), TQ treated (TQ group), A. sativum extract treated (A group) and their combination treated (TQA group) male rats for 4 weeks shows higher immune-reactivity of FSH (brown color) in treatment groups than control. IHC staining, $\mathrm{x} 400$. 


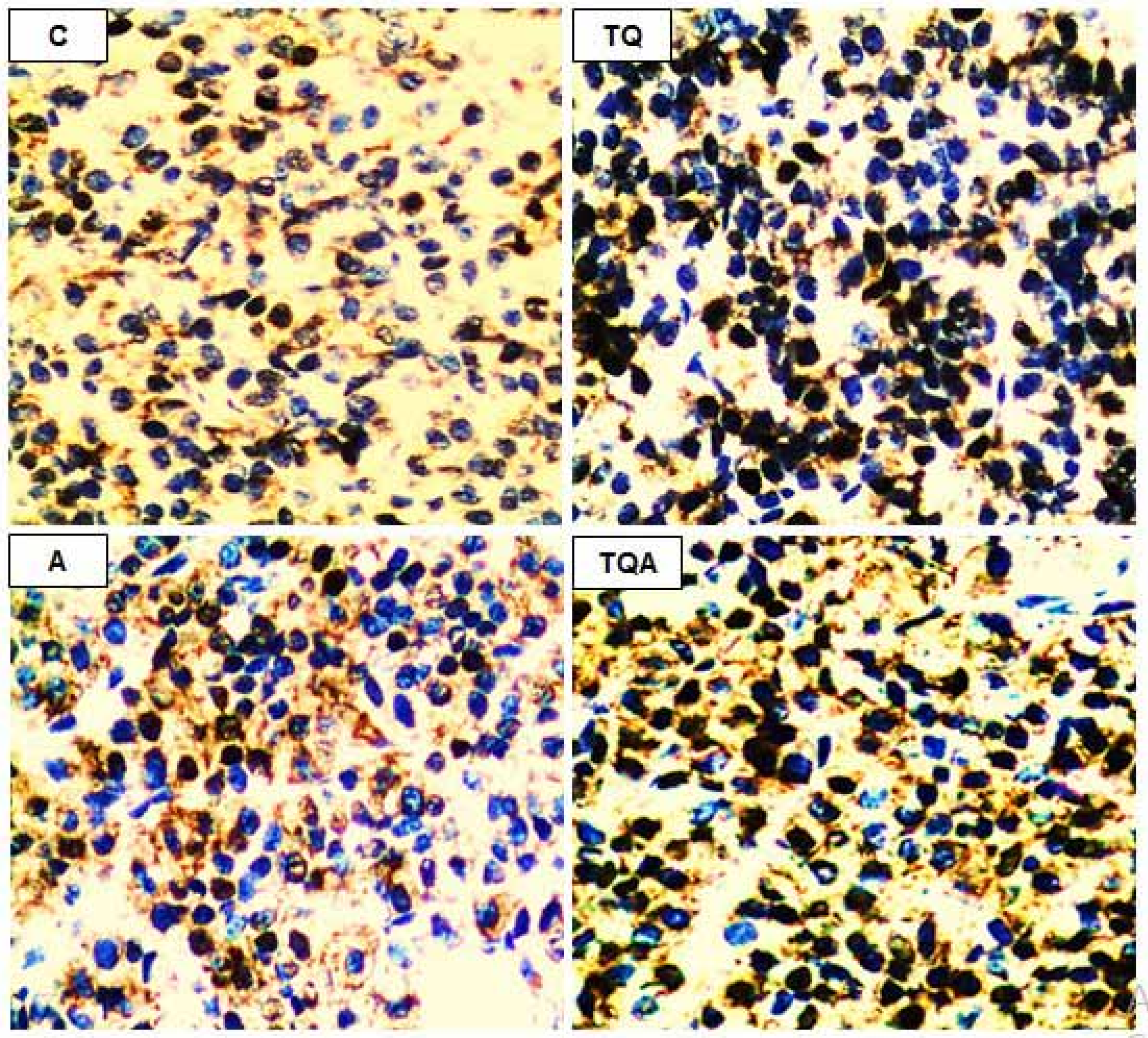

Figure (2): Sections obtained from adenohypophysis of control (C), TQ treated (TQ group), A. sativum extract treated (A group) and their combination treated (TQA group) male rats for 4 weeks shows higher immune-reactivity of LH (brown color) in treatment groups than control. IHC staining, $\mathrm{x} 400$.

In terms of Sertoli cells, for the first time, in previous studies, several Sertoli cell markers has been evaluated, where it has been found that crude garlic at $10 \%$ and $15 \%$ doses induced modifications in the expression of these markers (36). These modifications were associated with decrease in testosterone $(28,37)$ and FSH levels (36). Concerning germ cells, the results of previous studies revealed that the consumption of crude garlic over 1 month induces apoptosis of spermatocytes (pachytenes stage) and spermatids by the activation of caspase- 3 and the increase in Smac (pro-apoptotic protein) and IAPs (anti-apoptotic protein) (36). The apoptosis of germ cells was confirmed by the study of Abdelmalik (36), who described morphological aspects suggesting apoptosis of somatic and myoid cells of adult rat after treatment with $20 \%$ of crude garlic during 4 months.

The results of the present study showed a high expression of the testicular testosterone produced by the Leydic cells in male rats treated with TQ. The intensity of the immune reaction increased in TQ treated male rats, as 
the amount of the hormone lactic acid produced greater than the quantity in the rest of the groups and the strength of this reaction is due to the association of antibody to the testicular steroid with the antigen located in the Leydic cells. This is in agreement with Sasso-Cerri et al. (38), who studied the IHC of testicular steroids and primary germ cells in Rana catesbeiana. They confirmed that the testicular steroid hormones was excreted by the testicular interstitial cells in all animals and observed when using the immune reaction of Leydic cells. The results of the present study were consistent with that referred to Haseena et al. (39), who confirmed the effect of TQ in the improvement of testicular functions and raise the level of testicular steroid hormones in male rats.

In conclusion, TQ and Allium Sativum extract have potent roles in male reproduction by increasing reproductive hormones production which could improve the male fertility.

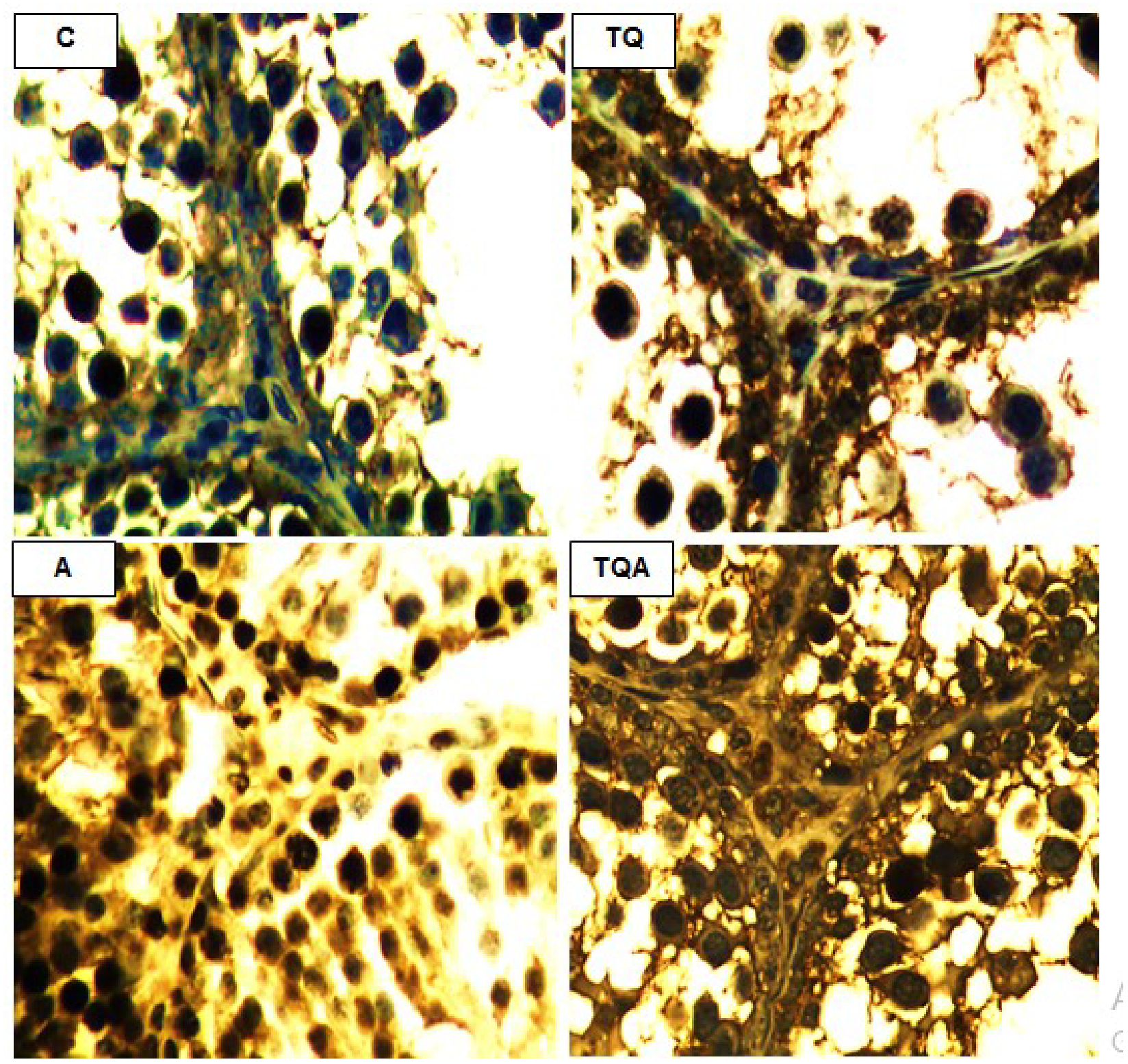

Figure (3): Sections obtained from testes of control (C), TQ treated (TQ group), A. sativum extract treated (A group) and their combination treated (TQA group) male rats for 4 weeks shows higher immune-reactivity of testosterone (brown color) in treatment groups than control. IHC staining, $\mathrm{x} 400$. 


\section{References}

1. Rahmani AH, and Aly SM. Nigella sativa and its active constituents Thymoquinone show pivotal role in the disease prevention and treatment.Asian J Pharm Clin Res. 2015;8(1):48-53.

2. Woo CC, Kumar AP, Sethi G, and Tan KHB. Thymoquinone: potential cure for inflammatory disorders and cancer. Biochem pharmacol. 2012;83:443-451.

3. Lupidi G, Scire A, Camaion EI, Khalife KH, De Sanctis G, Tanfani F, and Damiani E. Thymoquinone, a potential therapeutic agent of Nigella Sativa, binds to site I of human serum albumin. Phytomedicine.2010;17:714-720.

4. Moyers S. History of garlic. In: Garlic in Health، History and World Cuisine. Moyers S (ed.). Suncoast Press، St Petersburg, FL, 1996, pp:1-36.

5. Lawson LD. Garlic: a review of its medicinal effects and indicated active compounds. In: Phytomedicines of Europe Lawson LD, Bauer R (eds). Amer Chem Soc.Washington, DC, 1998; pp:176-209.

6. Rivlin RS. Historical perspective on the use of garlic. J Nutr. 2001;131:951-954.

7. Ginter E, and Simko V. Garlic (Allium sativum L and cardiovascular diseases. Bratisl Lek Listy. 2010;111:452-456.

8. Brankovic S, Radenkovic M, Kitic D, Veljkovic S, Ivetic V، Pavlovic $\mathrm{D}$, and Miladinovic B. Comparison of the hypotensive and bradycardic activity of ginkgo, garlic, and onion extracts. Clin Exp Hypertens. 2011;33:95-99.

9. Ola-Mudathir KF, Suru SM, Fafunso MA, Obioha UE, and Faremi TY. Protective roles of onion and garlic extracts on cadmium-induced changes in sperm characteristics and testicular oxidative damage in rats. Food Chem Toxicol. 2008;46:3604-3611.

10. Qian YX, Shen PJ, Xu RY, Liu GM, Yang HQ, Lu YS, Sun P، Zhang RW, Qi LM, and $\mathrm{Lu} \mathrm{QH}$. Spermicidal effect in vitro by the active principle of garlic. Contraception, 1986;34: 295-302.

11. Chakrabarti K, Pal S, and Bhattacharyya AK. Sperm immobilization activity of Allium sativum L. and other plant extracts. Asian J Androl. 2003;5:131-135.

12. Ivell R, Heng K, and Anand-Ivell R. Insulin-like factor 3 and the HPG axis in the male. Endocrinol. 2014;5:1-6.

13. Plant TM, and Witchel SF. Puberty in nonhuman primates and humans. In: Neill JD, editor. The Physiology of Reproduction. 3rd edn Academic Press/Elsevier; San Diego, 2006;2(40): 2177-2230.

14. Silverthorn DE, Johnson BR, Ober WC, Garrison CW, and Silverthorn AC. Reproduction and development. In: Silverthorn, D.U. Human physiology: an integrated approach. San Francisco, Pearson Education. 2010;828-862.

15. Melamed P. Hormonal signaling to follicle stimulation hormone $\beta-$ subunit gene expression. Mol Cell Endocrinol. 2010;314:202-212.

16. Forbes EE, and Dahl RE. Pubertal development and behavior: Hormonal activation of social and motivational tendencies. Brain Cognition. 2010;72: 66-72.

17. Sisk CL, and Zehr JL. Pubertal hormones organize the adolescent brain and behavior. Front Neuroendocrinol. 2005;26:163-174.

18. Harborne JB. Phytochemical Methods: A Guide to Modern Techniques of plant Analysis. Chapman and Hall, London, UK. 1984;pp:1- 34.

19. Al-Sa'aidi JAA, Al-Mayali HK, and Al-Jubory NO. Consecutive Liver Expression Levels of Cat, Cu-Zn-Sod1, Hsp70, and Gstm1 Genes in Heat Stressed Male Rats Treated with Thymoquinone. Int J Biol Pharm Allied Sci. 2016;5(9):2057-2069.

20. Al-Sa'aidi JAA, and Ali ZS. Hypolipidemic Effect of Thymoquinone in Heat Stressed Male Rats. AL-Qadisiyha J For Sci. 2016;21(2):1-9.

21. Humason G.Humason animal tissue techniques. $5^{\text {th }}$ ed.London. 1997.
22. Hussanin KMA, and Safwat MG. Role of Nigella Sativa oil in alleviating increased reproductive hormones and some inflammatory mediators caused by cadmium toxicity in rat testes. Int $\mathrm{J}$ Adv Res.2014;2(9):606-611.

23. Hull KL, and Harvey S. GH as a co- gonadotropin: the relevance of correlative changes in $\mathrm{GH}$ secretion and reproductive state. $\mathrm{J}$ Endocr. 2002:172:1-19.

24. Boukhliq R, Martin GB, White CL, Blachberry MA, and Murrry PJ. Role of glucose, fatty acids and protein in regulating of testicular growth and secretion of gonadotrophin, prolactin, somatotrophin and insulin in the mature ram. J Reprod Fertil. 1997;9:515-524.

25. Al-Sa'aidi JAA, Al-Khuzai ALD, and Al-Zobaydi NFH. Effect of alcoholic extract of Nigella sativa on fertility in male rats. Iraqi J Vet Sci. 2009;23:123-128.

26. Dixit VP, and Joshi S. Effects of chronic administration of garlic (Allium sativum L.) on testicular function. Ind $\mathrm{J}$ Exp Biol. 1982;20:534-536.

27. Al-Bekairi AM, Arif H, and Qureshi S. Effect of Allium sativum on epididymal spermatozoa, estradiol-treated mice and general toxicity. J Ethnopharm. 1990;29(2):117-125.

28. Hammami I, Nahdi A, Mauduit C, Benahmed M, Amri M, Ben Amar A, Zekri S, El May A, and El May MV. The inhibitory effects on adult male reproductive functions of crude garlic (Allium sativum) feeding. Asian J Androl. 2008;10:593-601.

29. Dixon RA. Phytoestrogens. Annu Rev Plant Biol. 2004;55:225-261.

30. Oi Y, Imafuku M, Shishido C, Kominato Y, Nishimura S, and Iwai K. Garlic supplementation increases testicular testosterone and decreases plasma corticosterone in rats fed a high protein diet. J Nutr. 2001;131:2150-2156.

31. Stocco DM. Intramitochondrial cholesterol transfer. Biochim Biophys Acta.2000;1486: 184-197.

32. Woolveridge I, de Boer-Brouwer M, Taylor MF, Teerds KJ, Wu FC, and Morris ID. Apoptosis in the rat spermatogenic epithelium following androgen withdrawal: changes in apoptosis-related genes. Biol Reprod. 1999;60:461-470.

33. Bakalska M, Atanassova N, Koeva Y, Nikolov B, and Davidoff M. Induction of male germ cell apoptosis by testosterone withdrawal after ethane dimethanesulfonate treatment in adult rats. Endocr Regul. 2004;38:103-110.

34. Campbell JH, Efendy JL, Smith NJ, and Campbell GR. Molecular basis by which garlic suppresses atherosclerosis. J Nutr. 2001;131:1006-1009.

35. Hughes PJ, McLellan H, Lowes DA, Kahn SZ, Bilmen JG, Tovey SC, Godfrey RE, Michell RH, Kirk CJ, and Michelangeli F. Estrogenic alkylphenols induce cell death by inhibiting testis endoplasmic reticulum $\mathrm{Ca}(2+)$ pumps. Biochem Biophys Res Commun.2000;277: $568-574$.

36. Hammami I, Amara S, Benahmed M, El May MV, and Mauduit C. Chronic crude garlic-feeding modified adult male rat testicular markers: mechanisms of action. Reprod Biol Endocrinol. 2009;24:5765.

37. Abdelmalik SW. Histological and ultrastructural changes in the adult male albino rat testes following chronic crude garlic consumption. Ann Anat. 2011;193:134-141.

38. Sasso-Cerri E. Freymüller E, and Miraglia SM. Testosterone immunopositive primordial germ cells in the testis of the bullfrog Rana, catesbeiana. Anatomical Society of Great Britain and Ireland, 2005; pp:519-523.

39. Haseena S, Aithal M, Das KK, and Saheb HS. Effect of Nigella Sativa seed powder on Testosterone and $\mathrm{LH}$ levels in Sterptozotocine induced diabetes male Albino Rats. J Pharm Sci Res. 2015;7(4):234237. 